Article Type: Research Paper

\title{
Fertility and Female Labor Force Participation in Asian Countries; Panel ARDL Approach
}

\author{
Nawalin Nazah*, Jarita Duasa, and Muhammad Irwan Arifin
}

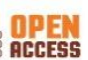

\section{AFFILIATION:}

Department of Economics, Faculty of Economics and Management Sciences, International Islamic University Malaysia, Malaysia

\section{*CORRESPONDENCE:}

nawalin12@gmail.com

THIS ARTICLE IS AVALILABLE IN:

http://journal.umy.ac.id/index.php/esp

DOI: 10.18196/jesp.v22i2.11142

\section{CITATION:}

Nazah, N., Duasa, J., \& Arifin, M.I. (2021). Fertility and Female Labor Force Participation in Asian Countries; Panel ARDL Approach. Jurnal Ekonomi \& Studi

Pembangunan, 22(2), 272-288.

\section{ARTICLE HISTORY}

Received:

13 Feb 2021

Revised:

$10 \mathrm{Jul} 2021$

Accepted:

14 Sep 2021
Abstract: Fertility has a close relationship with female labor force participation and is predicted to be the prominent factor affecting female labor force participation in rich and emerging countries. The decline in fertility worldwide, accompanied by increased female education, is assumed to increase female labor force participation. The increase in the female labor force participation rate can improve economic incentives for the country. Therefore, this study estimates the effect of fertility and female education on female labor force participation in cross-country panel datasets from 39 Asian countries, using panel ARDL analysis from 1990-2018. This study also examines the panel causality between the variables employing Dumitrescu and Hurlin's (2012) Granger non-causality test. According to the Hausman test, among the three models in panel ARDL, DFE is the preferred model compared to the PMG and MG. The results revealed that fertility was negatively significant on female labor participation in the short run but not in the long run. In contrast, female education was positively significant on female labor participation in the long run but not in the short run. Meanwhile, the panel causality showed a bidirectional relationship between female labor participation and fertility, female labor participation and education, and fertility and female education.

Keywords: Fertility; Female Labor Force Participation; Panel ARDL; Panel Causality; ASIAN countries

JEL Classification: C01, J11, J13, J22

\section{Introduction}

The relationship between female labor force participation (FLFP) and total fertility rate (TFR) has received much attention in the demographic and economic literature. It has also been debated in different regions and development levels around the world. In this regard, the presence of children affects the mother's activity, especially if the mother works a paid job. Mothers with young children have traditionally been considered to have low labor force attachment. The female labor force participation will also affect family size decisions. Thus, the discussion of female labor force participation cannot be separated from fertility as these two have a close relationship. Generally, the female labor force participation level tends to be high in countries with low fertility rates (Roser, 2014). 
Specifically, Asia is the largest continent, with $60 \%$ of the world's population. Asia also has the fastest growing economy, with a nominal GDP of $\$ 31.58$ trillion and a GDP per capita of $\$ 7,351$ in 2019. Asian wealth is mostly concentrated in East Asia, such as Japan, South Korea, Taiwan, Hong Kong, Macau, and Singapore. On the other hand, these countries are recorded as some of the countries with the lowest fertility in the world. Thus, it becomes the reason for choosing Asia as the study interest.

Despite becoming the fastest growing economy, female labor force participation in Asia has remained low while female education has improved significantly and the fertility trends have shown a dramatic decline. The two conditions are assumed to increase the rate of female labor force participation. It is also the reason why Asia is interesting to be investigated. In 2018, female labor force participation in Asia ranged from 5.98\% in Yemen to $81.6 \%$ in Nepal. Some prominent constraints in increasing female labor force participation are social norms that emphasize women's domestic responsibilities, limited mobility, restriction on the subset of jobs considered appropriate for women, and lack of access to information (Asian Development Bank, 2016).

Some studies such as Bloom et al. (2009) found a large negative effect of fertility on female labor force participation in 97 countries over 1960-2000, using abortion as an instrument and simulation variable. Nakagaki (2018) applied fixed effect and a random effect to 176 countries and documented the correlation that moved from negative to positive by the 1990s in OECD countries, while in the Asian-Pacific region, no clear pattern was reported between female labor force participation and fertility rates. In the Middle East and North Africa (MENA) countries, female labor force participation has continued to be lowest in the world as fertility decreased (Lim, 2002) through analysis. Even though these studies used a large panel data sample, they applied a different approach than this study. To the author's knowledge, the investigation on how fertility and female education influence female labor participation by applying the dynamic panel ARDL in the scope of Asian countries has not been found. Although the analysis of Shittu and Abdullah (2019) and Subramanian et al. (2016) using panel ARDL, it only covered ASEAN-7 and ASEAN-5 countries, respectively, which might not be enough for panel analysis and might lead to insufficient information. As for better results, the panel ARDL requires a large number of observations (countries). Thus, this study makes up for the shortcomings. Therefore, the objective of this study is to investigate the effect of fertility and female education on female labor force participation in 39 Asian countries between 1990-2018, using panel ARDL analysis and panel causality. This study also attempts to address potential policies to reduce obstacles to achieving higher female labor force participation levels.

Moreover, this study provides more knowledge about Asian countries, especially about fertility and female labor participation. The application of panel ARDL has many advantages that have not been widely used for analyzing fertility studies. Some advantages are that it provides alternative models, where the selection is based on the Hausman test. Meanwhile, the DFE estimation gives homogeneous coefficients for both long and short-run for all countries in the panel, while it contradicts the MG estimation with heterogeneous coefficients for all countries, for both short and long run, and allows 
the combination of homogeneous coefficients and the heterogeneous slopes in the longrun and short-run, respectively, for PMG estimation.

On the other hand, a dramatic decline in fertility leads to major changes in a population's age structure. Lower fertility causes a decrease in the youth dependency ratio, thereby increasing output per capita. Fertility reduction is expected to increase female labor market participation. Females' decisions to participate in the labor market are usually influenced by household factors, especially those who are married. Working females will contribute to family income, but at the same time, will lesser time for childcare and household chores; consequently, it will reduce household benefits.

Cho (2006), using a dynamic lifecycle model, argued that having children significantly reduces women's market time. It discourages women's labor supply by reducing the effective wage rate since they hire babysitters while working. The number of women dropping out of the labor market when the children are young and need intensive care is higher than in other periods. However, this temporary dropout is hardly found in developed countries due to the availability of childcare facilities and family-friendly labor market policies. In the case of Korea, the increase in the real wage of women was largely responsible for the growth of the female labor force.

In addition, Bloom et al. (2009) investigated that the strongest effect of fertility on female labor supply is during their fertile years and implies a reduction of about four years of paid work over a women's lifetime for an additional child. Meanwhile, Tiefenthaler (1997) compared the effects of birth on time allocation across households for the case of Cebu, the Philippines, and found that at 14 months after birth, female labor market hours declined by $39 \%$ in the case of first birth. However, it was only $10 \%$ if there were already children aged $0-5$ in the household, and it did not decrease if there were also children aged $6-17$ in the household.

Del Boca and Locatelli (2006) observed a negative relationship between fertility and female labor force participation in several OECD countries in the 1970s; however, the correlation became positive in the late 1980s. In contrast, Hupkau and Leturcq (2017) found that the family size did not impact employment for high and intermediate-skilled women, while for low-skilled women, the effect was large and inversely correlated in the long run. Moreover, Aaronson et al. (2017) uncovered that the effect of fertility on labor supply was small at a low level of development and negative at a higher level of development. However, Solomon and Kimmel (2009) failed to support an inverse relationship between fertility and labor supply in the case of Ethiopia, while Abbas (2013) disclosed a positive relationship for the case of Bangladesh and Pakistan, and Azimi (2015) found no effect in the case of Iran.

While some previous studies have focused on the consequences of fertility on female labor market participation due to the burden of childcare, mainly related to women, Kim and Aassve (2006) interestingly examined the effect of fertility on both males and females labor market in Indonesia. They analyzed the different responses between male and female laborers in urban and rural areas. Their results exposed that female laborers 
reduced 1.1 working hours per week per increase of one birth in rural and urban areas, while only male laborers in rural areas were affected by increasing their 0.9 working hours per increase of one childbirth. This situation was mostly caused by the differences in childcare costs between urban and rural areas rather than employment reasons. The involvement of both males and females is supported by the economic theory that an increase in fertility is likely to change the optimal time allocation within the household, thereby influencing the labor supply and the earnings for both males and females (Becker 1985).

Other than fertility, female education is also an essential factor contributing to female labor participation. An increase in female education has become a prominent factor in increasing female labor force participation, particularly in relatively high-paying jobs. It is because educated workers are a valuable resource for a country. Education also provides better employment opportunities for women and hence raises their incomes. In many countries, the level of female education has increased substantially over the past decades, accompanied by a decline in the fertility rate. Education raises women's status both in society and within the family and increases productivity at home (Becker, 1975) and workplace (Schultz, 1961). Women with higher levels of education are more likely to be active in the labor market. Higher levels of educational attainment and declined fertility lead to increased female labor force participation rates. Thus, education is an important factor that determines female labor force participation.

In addition, Anggaraini \& Setyari (2020) listed that knowledge, self-actualization, and the desire to achieve inner satisfaction are among the factors that driven women's decision to work besides economic factors. Moreover, working mothers have more power in decision making such as children's education. The study found that the relative income of working mothers significantly influences children's human capital for the case of Indonesia. This argument strengthens that education is an important factor for a female to participate in the paid work.

Skadsen (2017) stated that the average educational attainment for females significantly influenced female labor by using country-specific timing on contraceptive legislation. One-year additional education attainment is expected to increase the female labor participation rate by about $5.7 \%$ for 125 countries. Several studies that found a positive influence of education on women's labor supply are Nam (1991), Eun (2007), Lim (2017), Eckstein and Lifshitz (2011), Cameron et al. (2001), Abbas (2013), Hafeez and Ahmed (2002), and Chamlou et al. (2011). However, Heath and Jayachandran (2016) argued that increased education did not universally translate into a higher probability of working, as in the case of Pakistan. Moreover, Andrabi et al. (2012) also showed that education did not increase labor force participation. Hence, the causality of female labor participation and fertility is also investigated in this study to confirm whether there is a uni-directional, bi-directional, or no causal relationship. In addition, some studies have reported a unidirectional relationship between fertility rate and female labor participation, such as in Narayan and Smyth (2006) and Mishra and Smyth (2010). The causal relationship between fertility rate and female labor force participation does not necessarily exist; working women do not certainly have fewer children and having a small number of children does not always discourage maternal employment as found in Taiwan (Cheng, 1999). 
Nazah, Duasa, \& Arifin

Fertility and Female Labor Force Participation ...

\section{Research Method}

\section{Data}

The data used in this study were retrieved from the World Bank (2019) for data on fertility rate (TFR) and female labor force participation (FLFP) from 1990-2018 in the form of an annual time series. Meanwhile, female educational attainment, which is the average number of years of education received by people aged 25 and older, was taken from Barro and Lee (2013), Barro and Lee's projection, and the Singapore Department of Statistics. Data education attainment was in the form of five-year frequency; therefore, the data were interpolated into yearly form following Ulku (2004). Meanwhile, data on female educational attainment for Singapore was obtained from the Singapore Department of Statistics in annual form. The countries involved in this study were Indonesia, Malaysia, the Philippines, Thailand, Singapore, Vietnam, Cambodia, Brunei, India, Sri Lanka, Nepal, Pakistan, Bangladesh, China, Japan, Mongolia, South Korea, Turkey, Myanmar, Iran, Iraq, Yemen, Saudi Arabia, Afghanistan, Jordan, Kazakhstan, United Arab Emirates, Tajikistan, Israel, Laos, Kyrgyzstan, Kuwait, Armenia, Qatar, Bahrain, Cyprus, Maldives, Hong Kong, and Macau.

\section{Panel ARDL Estimation}

Before applying cointegration and causality tests, the stationary and integration level tests were first performed. For unit root, Levin, Lin \& Chu, Im, Pesaran, and Shin, Augmented Dickey-Fuller (ADF), and Phillips Perron tests were applied to test stationarity data and confirm that no series exceeded the integration of order I(1). The cointegration test was then held to check that all variables were cointegrated as the required conditions before estimating the panel ARDL. This study applied three cointegration tests: the Kao, the Pedroni, and the Westerlund tests.

The estimation of female labor force participation and fertility was conducted in a panel data framework using panel ARDL analysis based on the use of three alternative estimators: the mean group estimator (MG), the pooled mean group estimator (PMG), and the dynamic fixed effects (DFE) estimator. This study employed annual panel data of the selected macroeconomic indicators from ASIAN countries from 1990 to 2018. Panel data analysis involves a combination of cross-section $(N)$ and time series $(T)$ observations for analysis. In this study, N= 39 (countries) and T= 29 (from 1990-2018). The panel ARDL can simultaneously estimate the long-run and short-run parameters of the model yet avoid stationary data problems. Moreover, it is not necessary to determine the order of integration between variables in advance.

Based on Pesaran et al. (1999), the dynamic heterogeneous panel regression can be incorporated into the error-correction model using the autoregressive distributed lag $\operatorname{ARDL}(p, q)$ technique, where $p$ is the lag of the dependent variable and $q$ is the lag of the independent variables. The optimal lag is selected based on the AIC, which is more suitable and superior than other criteria in the case of a small sample lower than 60 crosssectional observations (Liew, 2004). It is because AIC minimizes the change of 
underestimation while maximizing the change of recovering the true lag length. According to AIC, the optimum lag for both dependent and independent variables is 4; however, having a lag of more than one will reduce the degree of freedom. Besides, this study only had 29 years, which was not long enough to overextend the lag. Therefore, the analyses in this study used a lag of one for both dependent and independent variables. It is supported by Pesaran et al. (1999) and Demetriades and Hook Law (2006), who stated that it is recommended to impose a common lag structure across countries under the limitation of the data.

The generalized ARDL $(p, q, q, \ldots q)$ model is specified as:

$y_{i t}=\sum_{j=1}^{p} \lambda_{i j} y_{i, t-j}+\sum_{j=0}^{q} \delta_{i j}^{\prime} X_{i, t-j}+\mu_{i}+\varepsilon_{i t}$

where $t=1,2, \ldots, T$ and, $i=1,2, \ldots . N$,

where $y_{i t}$ is the dependent variable (female labor force participation), $X_{i t}$ is a $k x 1$ vector of explanatory variables (fertility rate and female education) allowed to be purely $I(0)$ or I(1) or cointegrated. $\mu_{i}$ is the fixed effects, $\lambda_{i j}$ is the coefficient of the lagged dependent variable called a scalar. $\delta_{i j}^{\prime}$ is $k \times 1$ coefficient vectors. $p, q$ are optimal lag order, and $\varepsilon_{i, t}$ is the error term.

The re-parameterized ARDL $(p, q, q, \ldots . q)$ error correction model is specified as:

$\Delta y_{i t}=\phi_{i} y_{i, t-1}+\beta_{i}^{\prime} X_{i, t}+\sum_{j=1}^{p-1} \lambda_{i j}^{*} \Delta y_{i, t-j}+\sum_{j=0}^{q-1} \delta_{i j}^{* \prime} \Delta X_{i, t-j}+\mu_{i}+\varepsilon_{i t}$

where $y$ is the total fertility rate, and $X$ is a set of independent variables.

$i=1,2, \ldots, N$ and $t=1,2, \ldots, T$

where $\phi_{i}=-\left(1-\sum_{j=1}^{p} \lambda_{i j}\right), \beta_{i}=\sum_{j=0}^{q} \delta_{i j}, \lambda_{i j}^{*}=-\sum_{m=j+1}^{p} \lambda_{i m}, j=1,2, \ldots, p-1$ and $\delta_{i j}^{*}=-\sum_{m=j+1}^{q} \delta_{i m}, j=1,2, \ldots, q-1$

If there are t observations for each group, equation (3.2) can be written as:

$\Delta y_{i}=\phi_{i} y_{i,-1}+X_{i} \beta_{i}+\sum_{j=1}^{p-1} \lambda_{i j}^{*} \Delta y_{i,-j}+\sum_{j=0}^{q-1} \Delta X_{i,-j} \delta_{i j}^{*}+\mu_{i} l+\varepsilon_{i}$

$i=1,2, \ldots ., N$, and $y_{i}=\left(y_{i 1}, \ldots . y_{i T}\right)^{\prime}$ is a $T x 1$ vector of the observation on the dependent variable of the $i^{\text {th }}$ group, $X_{i}=\left(x_{i 1}, \ldots . x_{i T}\right)^{\prime}$ is a $T x k$ matrix of observations on the regressors that vary both cross groups and periods, $l=(1, \ldots .1)^{\prime}$ is a $T x 1$ vector of $1 \mathrm{~s}, y_{i,-j}$ and $X_{i,-j}$ is $j$ period lagged values of $y_{i}$ and $X_{i}$ and $\Delta y_{i}=y_{i}-y_{i-1}, \Delta X_{i}=X_{i}-$ $X_{i,-1}, \Delta y_{i}$ and $\Delta X_{i,-j}$ are $j$ period lagged values of $\Delta y_{i}$ and $\Delta X_{i}$ and $\varepsilon_{i}=\left(\varepsilon_{i 1}, \ldots \varepsilon_{i T}\right)^{\prime}$.

Pesaran et al. (1999) asserted that panel ARDL could be used with variables with a different order of integration; the short-run and long-run effects can be estimated simultaneously from a data set with cross-section and time dimensions. The ARDL model 
also produces consistent coefficients despite the possibility of endogeneity because it includes the lags of dependent and independent variables (Pesaran et al., 1999). The key features of the three different panel ARDL estimators are presented as follows.

\section{Pooled Mead Group (PMG)}

The salient feature of PMG is that it allows the short-run coefficients, including the intercepts, the speed of adjustment, and the error variances, to be heterogeneous between countries, while in the long-run coefficients, it is homogenous across countries. However, there are several requirements for the validity, consistency, and efficiency of this methodology.

1. First, the existence of a long-run relationship between the variables of interest requires the coefficient on the error-correction term to be negative.

2. An important assumption for the consistency of the ARDL model is that the residuals resulting from the error-correction model are serially uncorrelated, and the explanatory variables can be treated as exogenous.

3. The relative size of $T$ and $N$ is crucial since when both are large, it allows the researchers to use the dynamic panel technique, which helps avoid bias in the mean estimators and resolves the heterogeneity issue.

Mean Group (MG)

The mean group estimates separate regression for each country, both for the long-run and short-run, and the coefficients are calculated as unweighted means of the estimated coefficients for each country. Thus, it allows all coefficients to be heterogeneous in the long-run and short-run. However, this method needs to have a sufficiently large time series $(\mathrm{T})$ and cross country $(\mathrm{N})$, covering 20 to 30 countries to keep the results' consistency and validity.

Dynamic Fixed Effect (DFE)

The dynamic fixed effect estimator restricts the coefficients of the cointegrating vector to be equal across all panels. It also limits the speed of the adjustment coefficients and the short-run coefficients to be identical for all countries. However, it allows for countryspecific intercepts.

Model Selection

To select the best models among the PMG, MG, and DFE estimators, the Hausman test was employed to test whether there was a significant difference among these estimators. The test's null hypothesis is no significant difference between PMG and MG or between PMG and DFE. If the probability value is less than 0.05 , the decision is to reject the null hypothesis. If the null hypothesis is not rejected, the PMG estimator is preferred. 
To investigate the direction of causality between fertility and female labor force participation, Dumitrescu and Hurlin Granger's non-causality test was applied. The equations are written as follow:

$$
\begin{aligned}
& F_{L F P_{t}}=\alpha_{o 1}+\sum_{i=1}^{p} \beta_{1 i} F_{L F P_{t-i}}+\sum_{i=1}^{q} \beta_{2 i} T F R_{t-i}+u_{1 t} \quad \text { 2c } \\
& T F R_{t}=\alpha_{o 2}+\sum_{i=1}^{p} \delta_{1 i} T_{F R}+i+\sum_{i=1}^{q} \delta_{2 i} F L F P_{t-i}+u_{2 t} \quad 2 \mathrm{~d} \\
& F L F P_{t}=\alpha_{o 3}+\sum_{i=1}^{p} \theta_{1 i} F L F P_{t-i}+\sum_{i=1}^{q} \theta_{2 i} F E D U_{t-i}+u_{3 t} \quad 2 \mathrm{e} \\
& F E D U_{t}=\alpha_{o 4}+\sum_{i=1}^{p} \phi_{1 i} F E D U_{t-i}+\sum_{i=1}^{q} \phi_{2 i} F L F P_{t-i}+u_{4 t} \\
& F E D U_{t}=\alpha_{o 5}+\sum_{i=1}^{p} \gamma_{1 i} F E D U_{t-i}+\sum_{i=1}^{q} \gamma_{2 i} T F R_{t-i}+u_{5 t} \quad 2 \mathrm{~g} \\
& T F R_{t}=\alpha_{o 6}+\sum_{i=1}^{p} \mu_{1 i} T_{F R}+i+\sum_{i=1}^{q} \mu_{2 i} F E D U_{t-i}+u_{6 t} \quad 2 \mathrm{~h}
\end{aligned}
$$

If the coefficient of the lagged fertility (TFR) in (2c) $\beta_{2 i}$ is significantly different from zero, and the set of estimated coefficients of lagged female labor (FLFP) in (2d) $\delta_{2 i}$ is not significantly different from zero, it means there is uni-directional causality from fertility to female labor and vice versa. If both coefficient $\beta_{2 i}$ and $\delta_{2 i}$ are significantly different from zero; thus, FLFP and TFR perform bi-direction causality. If both coefficient $\beta_{2 i}$ and $\delta_{2 i}$ are not significantly different from zero; thus, FLFP and TFR are independent. A similar interpretation for the equations (2e) and ( $2 \mathrm{f}$ ) is for female labor-female education, and equations $(2 \mathrm{~g})$ and $(2 \mathrm{~h})$ are for female education-fertility.

\section{Result and Discussion}

The effect of fertility on female labor force participation was evaluated in this section using panel ARDL methods. Besides, female education was included as the explanatory variable. The descriptive statistic and correlation coefficients for the estimated variables are in Table 1 and Table 2.

\section{Descriptive Statistics}

Female labor participation ranged from the lowest of almost $6 \%$ for Yemen in 2018 to 82 $\%$ for Nepal in 2018. The TFR was 0.86 for the lowest in Macau in 2003, and the highest was in Yemen at 8.6 children per woman in 1990. For female education, the number started at 0.1 years in Yemen in 1990, and the highest was 13.6 years in South Korea in 2018. 
Nazah, Duasa, \& Arifin

Fertility and Female Labor Force Participation ...

Table 1 Descriptive Statistics

\begin{tabular}{lccccc}
\multicolumn{1}{c}{ Variable } & Obs & Mean & Std. Dev. & Min & Max \\
\hline FLFPR & 1.131 & 45.61963 & 18.81566 & 5.983 & 81.841 \\
TFR & 1.131 & 2.840403 & 1.357057 & 0.86 & 8.606 \\
F_EDU & 1.131 & 6.641326 & 3.197232 & 0.1 & 13.6 \\
\hline
\end{tabular}

Table 2 Correlation Coefficients

\begin{tabular}{lccc} 
& FLFPR & TFR & F-EDU \\
\hline FLFPR & 1 & & \\
TFR & -0.3626 & 1 & \\
F-EDU & 0.1214 & -0.5894 & 1 \\
\hline
\end{tabular}

Table 2 shows the correlation between variables, and it can be seen that fertility and female labor force participation had a negative correlation, likewise for fertility and female education. Meanwhile, there was a positive correlation between female education and female labor participation.

Panel Unit Root Test

Table 3 displays the unit root test of the variables involved. Fertility was stationary, while female labor force participation and female education were stationary at first. The stationary test was held to ensure that there was no second-order integration. Due to mixed levels of integration between the series, the study thus proceeded to apply the panel ARDL approach rather than the traditional static panel model.

Table 3 Unit Root Test

\begin{tabular}{lcccc}
\hline Variable & LLC & Im, PS & ADF & PP \\
\hline TFR Level & $-16.396^{* * *}$ & $-12.879^{* * *}$ & $388.592^{* * *}$ & $398.534^{* * *}$ \\
& $(0.000)$ & $(0.000)$ & $(0.000)$ & $(0.000)$ \\
FLPR Level & $-3.0748^{* * *}$ & $0.64297(0.7399)$ & $92.7915(0.1211)$ & $90.2375(0.1622)$ \\
& $(0.0011)$ & & & \\
FLPR 1 $1^{\text {st }}$ diff & $-8.2161^{* * *}$ & $-12.020^{* * *}$ & $327.055^{* * *}$ & $361.541^{* * *}$ \\
& $(0.0000)$ & $(0.0000)$ & $(0.0000)$ & $(0.0000)$ \\
F-EDU Level & $-3.3188^{* * *}$ & $3.24314(0.9994)$ & $62.3638(0.9019)$ & $83.4584(0.3155)$ \\
& $(0.0005)$ & & & \\
F-EDU 1 $1^{\text {st }}$ & $-6.9218^{* * *}$ & $-4.2056^{* * *}$ & $199.381^{* * *}$ & $407.995^{* * *}$ \\
diff & $(0.0000)$ & $(0.0000)$ & $(0.0000)$ & $(0.0000)$ \\
\hline
\end{tabular}

Source: Author's calculations using EViews and STATA. Numbers between parentheses refer to the probability of the test statistics. The null hypothesis of these tests is that the panel series has a unit root. Notes: ${ }^{*}, *$, and ${ }^{* * *}$ indicate significance at $10 \%$, at $5 \%$, and at $1 \%$.

\section{Panel Cointegration Test}

Panel cointegration tests were performed to ensure that the variables were cointegrated before running the panel ARDL estimation and panel causality tests. According to the Pedroni (1999) and Kao (1999) tests, the probabilities showed significance at a one percent level, while the probability was insignificant for the Westerlund test. Saying that 
two among three tests were cointegrated, it can be concluded that there was cointegration among the model variables.

Table 4 Cointegration Test

\begin{tabular}{|c|c|c|c|c|c|}
\hline \multicolumn{2}{|c|}{ Pedroni test } & \multicolumn{2}{|l|}{ Kao test } & \multicolumn{2}{|c|}{ Westerlund test } \\
\hline Modified & $3.9002 * * *$ & Modified Dickey- & $3.5141 * * *$ & Variance & -0.3640 \\
\hline Phillips-Perron $t$ & $(0.0000)$ & Fuller $\mathrm{t}$ & $(0.0002)$ & ratio & (0.3579) \\
\hline \multirow[t]{2}{*}{ Phillips-Perron $t$} & $2.5475 * * *$ & Dickey-Fuller t & $3.0211 * * *$ & & \\
\hline & $(0.0054)$ & & $(0.0013)$ & & \\
\hline \multirow{6}{*}{$\begin{array}{l}\text { Augmented } \\
\text { Dickey-Fuller t }\end{array}$} & $3.5278 * * *$ & Augmented Dickey- & $2.5997 * * *$ & & \\
\hline & $(0.0002)$ & Fuller $\mathrm{t}$ & $(0.0047)$ & & \\
\hline & & Unadjusted Modified & $3.9957 * * *$ & & \\
\hline & & Dickey-Fuller t & $(0.0000)$ & & \\
\hline & & Unadjusted Dickey- & $3.7152 * * *$ & & \\
\hline & & Fuller $\mathrm{t}$ & $(0.0001)$ & & \\
\hline
\end{tabular}

Source: Author's calculations using STATA. Numbers between parentheses refer to the probability of the test statistics. The null hypothesis of these tests is that there is no cointegration. Notes: ${ }^{*}$, **, and $* * *$ indicate significance at $10 \%$, at $5 \%$, and at $1 \%$.

Panel ARDL estimation

According to Table 5, between PMG and MG model, the Hausman test result showed that the $p$-value (the number in the parentheses) was 0.0359 , less than 0.05 . Under the null hypothesis that PMG is more efficient, the null hypothesis was rejected; thus, MG was a consistent and efficient estimation than PMG. For the second Hausman test, comparing PMG and DFE, the p-value was 0.000 , giving the consequence that DFE was a better estimation than PMG under the null hypothesis that PMG is more efficient. For the third Hausman test comparing MG and DFE, the probability was 0.7249 ; thus, it failed to reject the null hypothesis. In other words, DFE was a better estimation than MG, under the null hypothesis that DFE is more efficient than MG. Hence, it can be concluded that among the three models, DFE was the best estimation. The ECT or the speed of convergence to equilibrium was significant at a one percent level, indicating long-run cointegration among the variables in the panel. Any deviations from long-run equilibrium were corrected at $3.27 \%$ adjustment speed.

Therefore, the result interpretation referred to the DFE as the best estimation according to the Hausman test. Once again, the DFE estimation restricts the coefficients of the cointegrating vector to be homogeneous across all panels and limits the speed of adjustment coefficients and the short-run coefficients to be identical for all countries. In the long run, the fertility coefficient was negative, yet it was not significant. Fertility did not significantly affect female labor force participation in the long run. It might be due to the flexibility of job roles, such as maternity leave; after mothers deliver a baby within a certain period, they will return to continue their work. Azimi (2015) supports the finding whereby no effect of fertility on female employment in the case of Iran. Hupkau and Leturcq (2016) also found that family size did not impact employment for high- and intermediate-skilled women, but the effect was large and inversely correlated in the long run for low-skilled women. 
Nazah, Duasa, \& Arifin

Fertility and Female Labor Force Participation ...

Table 5 Panel ARDL estimation

\begin{tabular}{|c|c|c|c|c|c|c|}
\hline \multirow[t]{2}{*}{ D.LFLPR } & \multicolumn{2}{|c|}{ Pooled Mean Group } & \multicolumn{2}{|c|}{ Mean Group } & \multicolumn{2}{|c|}{ Dynamic Fixed Effect } \\
\hline & Coefficient & Std. Err & Coefficient & Std. Err & Coefficient & Std. Err \\
\hline \multicolumn{7}{|l|}{ LR } \\
\hline TFR & $2.615547^{* * *}$ & 0.251522 & -8.0487 & 7.449 & -0.5334 & 1.47127 \\
\hline F-EDU & $2.567861 * * *$ & 0.25364 & -0.2715 & 2.449 & $1.3533^{*}$ & 0.724538 \\
\hline \multicolumn{7}{|l|}{ SR } \\
\hline ECT & $-0.0343^{*}$ & 0.018729 & $\begin{array}{c}- \\
0.2105 * * *\end{array}$ & 0.0298 & $\begin{array}{c}- \\
0.0327 * * *\end{array}$ & 0.007495 \\
\hline$\triangle \mathrm{TFR}$ & 0.451256 & 1.314491 & 4.7147 & 3.1283 & $\begin{array}{c}- \\
0.83955^{* *}\end{array}$ & 0.400212 \\
\hline$\Delta \mathrm{F}-\mathrm{EDU}$ & 0.063444 & 0.135565 & 0.0290 & 0.852 & 0.029524 & 0.048539 \\
\hline Intercept & $1.162044^{*}$ & 0.617529 & 8.9529 & $1.9109 * * *$ & $1.3437 * * *$ & 0.432417 \\
\hline \multicolumn{7}{|c|}{ Hausman test } \\
\hline \multicolumn{3}{|c|}{ PMG, MG $\gg$ MG } & \multicolumn{2}{|c|}{$6.65^{1}(0.0359)$} & \multirow{2}{*}{\multicolumn{2}{|c|}{$38.12^{2}(0.0000)$}} \\
\hline \multicolumn{3}{|c|}{ PMG, DFE $\gg$ DFE } & & & & \\
\hline \multicolumn{3}{|c|}{ MG, DFE $\gg$ DFE } & & & \multicolumn{2}{|c|}{$0.64^{3}(0.7249)$} \\
\hline
\end{tabular}

Notes: $*, * *$, and $* * *$ indicate significance at $10 \%$, at $5 \%$, and at $1 \%$. Estimations are done by using xtpmg in Stata. The pooled mean group, mean group, and dynamic fixed effects control country and time effects. While the first panel (LR) shows long-run effects, the second panel reports both short-run effects (SR) and the speed of adjustment (ECT). The lag structure is ARDL $(1,1,1,1,1,1)$. The data are from 1990-2018.

Another reason is the availability of childcare services that provide facilities and services to care for babies, thus enabling mothers to do works. This condition is easily found in developed countries, such as South Korea, Singapore, and Japan (Cho, 2006). Besides, family-friendly labor market policies also contribute to the convenience and ease of working mothers while having small children at home. Hence, the presence of children does not affect female labor participation in the long run.

Meanwhile, in the short run, fertility was negatively significant at a five percent level. The fertility coefficient can be interpreted that one unit of fertility rate for each increase will reduce the percentage of female labor force participation by 0.84 . This result aligns with the expectation that any increase in fertility will reduce female labor participation and is supported by the studies of Tsani et al. (2013) and Mishra and Smyth (2010). The presence of children discourages women from taking part in the labor force, especially if the husband earns a high income that can meet all the family's needs. According to Chevalier and Viitanen (2002), the negative relationship was also motivated by the lack of childcare facilities, which could constrain women to participate in labor. Furthermore, social culture or religion may also contribute to the limitation of women for only doing domestic activities and taking care of their children. Shittu and Abdullah (2019) considered that this condition similarly happened in the past period in Malaysia, Brunei, Myanmar, and Indonesia, in which most of the population is Muslim. It is believed that in Islam, the wife's priority role is to do domestic activities, such as taking care of their children. In addition, lower fertility rates free up time for married women, thereby encouraging them to enter the labor force. As women increasingly participate in the labor market, their opportunity cost for having children raises. For this reason, they tend to have fewer children. 
Furthermore, female education was significantly positive on female labor force participation at a ten percent level in the long run. The coefficient explains that any additional one year of female education attainment will significantly increase the female labor participation rate by 1.35 . The finding supports the expectation that education plays a crucial role in determining female participation in economic activities. As the education level of females increases, the woman starts to get more share in the labor force. In this case, education raises job opportunities, including for females.

In this study, female education was significant in increasing the welfare of societies and families because it raised women's productivity through labor market participation. Here, education provides the basic skill to empower females and enhances women's status in society. The female probability of participating in economic activities is higher as the level of education increases. Educated women also encourage more on children's education hence producing a good future generation.

In the short run, however, the effect of female education on female labor participation was not significant. The impact of any improvement in education could not immediately change the participation of females in the labor market. Nevertheless, it took a certain period to be translated into skills, and human capital improvement from education is an investment in human capital. It is reinforced by Becker's (1964) human capital theory, stating that education is an investment due to the expected return in the future.

According to the Asian Development Bank (2016), female labor force participation does not necessarily increase with education; narrowing education gaps is insufficient to bring more women into work. The phenomena can be seen in some countries in Asia. For example, in China, more educated women are less likely to work. Meanwhile, in Pakistan, women with intermediate education are less likely to work than women with low or advanced education. In Indonesia, diagnostics suggest a higher demand for educated and skilled female workers, particularly in urban areas. In China, in rural areas, both male and female labor force participation rates decrease with educational attainment, though more steeply for women. However, in urban areas, participation rises with educational attainment, particularly for women.

\section{Causality Fertility-Female Labor}

To investigate the causal relationship between female labor force participation and fertility rate, the study applied the causality test by Dumitrescu and Hurlin (2012) to test Granger causality in panel datasets. As presented in Table 6, under the null hypothesis that fertility does not Granger-cause female labor participation, the results showed that the null hypothesis was rejected at a one percent level, indicating that fertility caused female labor participation. Besides, for the second null hypothesis, stating that female labor participation does not Granger-cause fertility, the results revealed rejection of the null hypothesis as the probability value was significant at one percent level. Thus, there was a consistency of a bidirectional relationship between female labor force participation and fertility. In other words, fertility is both a trigger and a consequence of female labor force participation. Bi-direction relationships between female labor participation and fertility were also found in the study done by Engelhardt et al. (2004) in the case of France, 
Italy, West Germany, and the United Kingdom for 1960-1994. A more recent study conducted by Subramanian et al. (2016) similarly revealed bidirectional causality between fertility and female labor participation for the case of ASEAN-5 countries. Other supporting findings of the bi-directional relationship could be found in Mishra and Smyth (2010) for OECD countries and Salamaliki et al. (2012) for the case of the United States.

Table 6 Dumitrescu \& Hurlin's (2012) Granger Non-Causality Test

\begin{tabular}{lcc}
\hline \multicolumn{1}{c}{ Null Hypothesis } & Statistic & P-value \\
\hline TFR does not Granger-cause FLFPR & W-bar $=5.0853$ & \\
FLFPR does not Granger-cause TFR & Z-bar $=18.0404$ & 0.0000 \\
& Z-bar tilde $=15.1947$ & 0.0000 \\
F_EDU does not Granger-cause FLFPR & W-bar $=12.4924$ & \\
& Z-bar $=50.7489$ & 0.0000 \\
FLFPR does not Granger-cause F_EDU & Z-bar tilde $=43.3431$ & 0.0000 \\
& W-bar $=3.1543$ & \\
F_EDU does not Granger-cause TFR & Z-bar $=9.5131$ & 0.0000 \\
& Z-bar tilde $=7.8564$ & 0.0000 \\
TFR does not Granger-cause F_EDU & W-bar $=3.4503$ & \\
& Z-bar $=10.8201$ & 0.0000 \\
& Z-bar tilde $=8.9811$ & 0.0000 \\
& W-bar $=8.8850$ & \\
& Z-bar $=34.8192$ & 0.0000 \\
& Z-bar tilde $=29.6343$ & 0.0000 \\
\hline
\end{tabular}

Source: Author's calculation using xtgcause in Stata

In this study, a bi-direction relationship also exists between female labor participation and female education and between fertility and female education, as shown by the probability value being significant at one percent level. Hence, it can be concluded that female education is both the cause and the consequence of female labor participation and fertility.

\section{Conclusion}

The study investigates the relationship between fertility, female education, and female labor participation and concludes that fertility and female education significantly impacted female labor force participation in Asian countries based on panel ARDL estimation. Meanwhile, fertility was negatively significant in the short run; however, female education was positively significant in the long run. In this regard, female participation in the labor market plays a pivotal role in advancing the countries' economies. Thus, it needs appropriate policies to be taken to encourage women to participate in the labor force. To enhance women's participation in the labor force, the government should have policies to reduce fertility rates, such as promoting the familyplanning program by encouraging contraceptives, increasing the quality of maternal and child health, and reducing child mortality. The policies to reduce fertility, especially for 
those countries with high fertility, are mostly for emerging countries. However, for low fertility countries, the government needs to encourage fertility to prevent labor shortages in the future. The provision of childcare facilities and services and family-friendly working policies can be addressed to motivate women to participate in the labor market regardless of the presence of children. Moreover, increasing female education is crucial since females are more likely to participate in economic and business activities as the education level increases. Females with education have more opportunities to get better jobs and have more options to select jobs. Even though mothers work from home while taking care of their children, educated women have higher possibilities to earn more income.

Some recommendations for future research are that studies can be made into groups based on income, such as high-income countries and low-income countries. Another suggestion for classification can also be based on low-fertility and high-fertility rate countries to see the comparison.

\section{References}

Aaronson, D., Dehejia, R., Jordan, A., Pop-Eleches, C., Samii, C., \& Schulze, K. (2017). The effect of fertility on mothers' labor supply over the last two centuries. NBER Working Paper 23717. https://doi.org/10.3386/w23717

Abbas, A. (2013). Determinants of women's labor supply in Bangladesh and Pakistan. Master Thesis. Umea Universitet.

Andrabi, T., Das, J., \& Khwaja, A.I. (2012). What did you do all day?: maternal education and child outcomes. Journal of Human Resources 47(4), 873-912. Retrieved from https://www.muse.jhu.edu/article/488615

Anggaraini, N., \& Setyari, N. (2020). The impact of working mothers' bargaining power on their children's human capital in Indonesia. Jurnal Ekonomi \& Studi Pembangunan, 21(2), 235-248. https://doi.org/10.18196/jesp.21.2.5044

Asian Development Bank. (2016). Female labor force participation in Asia: key trends, constraints, and opportunities. Retrieved from https://www.adb.org/sites/default/files/publication/209666/female-labor-forceparticipation-asia.pdf

Azimi, E. (2015). The effect of children on female labor force participation in urban Iran. IZ A Journal of Labor \& Development, 4(1). https://doi.org/10.1186/s40175-015-0030-x

Barro, R. J., \& Lee, J. W. (2013). A new data set of educational attainment in the world, 1950-2010. Journal of Development Economics, 104, 184-198. https://doi.org/10.1016/i.jdeveco.2012.10.001

Becker, G. S. (1964). Human capital: a theoretical and empirical analysis with special reference to education, (1st Edition). Cambridge: National Bureau of Economic Research.

Becker, G. S. (1975). Human capital: a theoretical and empirical analysis with special reference to education, (2nd Edition). Cambridge: National Bureau of Economic Research.

Becker, G. S. (1985). Human capital, effort, and the sexual division of labor. Journal of Labor Economics, 3(1, Part 2), S33-S58. https://doi.org/10.1086/298075

Bloom, D. E., Canning, D., Fink, G., \& Finlay, J. E. (2009). Fertility, female labor force participation, and the demographic dividend. Journal of Economic Growth, 14(2), 79-101. https://doi.org/10.1007/s10887-009-9039-9 
Cameron, L. A., Malcolm Dowling, J., \& Worswick, C. (2001). Education and labor market participation of women in Asia: Evidence from five countries. Economic Development and Cultural Change, 49(3), 459-477. https://doi.org/10.1086/452511

Chamlou, N., Muzi, S., \& Ahmed, H. (2011). Understanding the determinants of female labor force participation in the Middle East and North Africa Region: the role of education and social norms in Amman. Almalaurea Working Papers No. 31. Retrieved from http://www.almalaurea.it/universita/pubblicazioni/wp

Cheng, B. S. (1999). Cointegration and causality between fertility and female labor participation in Taiwan: A multivariate approach. Atlantic Economic Journal, 27(4), 422434. https://doi.org/10.1007/bf02298338

Chevalier, A., \& Viitanen, T. K. (2002). The causality between female labour force participation and the availability of childcare. Applied Economics Letters, 9(14), 915-918. https://doi.org/10.1080/13504850210138469

Cho, Y. (2006). An analysis of women's fertility and labor supply: implications for family policies. International Conference on Declining Fertility in East and Southeast Asian Countries. PIE and COE/RES, Hitotsubashi University. Retrieved from https://cis.ier.hitu.ac.jp/Common/pdf/dp/2006/dp290.pdf

Del Boca, D., \& Locatelli, M. (2006). The determinants of motherhood and work status: a survey. Institute of Labor Economics (IZA) Discussion Papers 2414. Retrieved from https://d-nb.info/993085393/34

Demetriades, P., \& Hook Law, S. (2006). Finance, institutions and economic development. International Journal of Finance \& Economics, 11(3), 245-260. https://doi.org/10.1002/iife.296

Dumitrescu, E.-I., \& Hurlin, C. (2012). Testing for Granger non-causality in heterogeneous panels. Economic Modelling, 29(4), 1450-1460. https://doi.org/10.1016/i.econmod.2012.02.014

Eckstein, Z., \& Lifshitz, O. (2011). Dynamic female labor supply. Econometrica, 79(6), 16751726. https://doi.org/10.3982/ecta8803

Engelhardt, A., Pfeifer, J.-B., Heistermann, M., Niemitz, C., van Hooff, J. A. R. A. M., \& Hodges, J. K. (2004). Assessment of female reproductive status by male longtailed macaques, Macaca fascicularis, under natural conditions. Animal Behaviour, 67(5), 915924. https://doi.org/10.1016/i.anbehav.2003.09.006

Eun, K.-S. (2007). Lowest-low fertility in the Republic of Korea: Causes, consequences and policy responses. Asia-Pacific Population Journal, 22(2), 51-72. https://doi.org/10.18356/742d2082-en

Hafeez, A., \& Ahmed, E. (2002). Sustainable Development Policy Institute. Working Paper, No 74; 2002. Retrieved from http://arks.princeton.edu/ark:/88435/dsp01zp38wg01p

Heath, R., \& Jayachandran, S. (2016). The causes and consequences of increased female education and labor force participation in developing countries. NBER Working Paper Series. https://doi.org/10.3386/w22766

Hupkau, C., \& Leturcq, M. (2017) Fertility and mothers' labor supply: new evidence usingtime-to-conception. CEP Discussion Paper (CEPDP1463). Retrieved from http://eprints.lse.ac.uk/id/eprint/69045

Kao, C. (1999). Spurious regression and residual-based tests for cointegration in panel data. Journal of Econometrics, 90(1), 1-44. https://doi.org/10.1016/s0304-4076(98)00023-2

Kim, J., \& Aassve, A. (2006). Fertility and its consequence on family labor supply. IZA Discussion Paper No. 2162. Retrieved from https://ftp.iza.org/dp2162.pdf

Liew, V.K-S. (2004). Which lag length selection criteria should we employ? Economics Bulletin, 3(33), 1-9. Retrieved from http://www.economicsbulletin.com/2004/volume3/EB04C20021A.pdf 
Lim, F.Y.B. (2017). The effects of education and fertility on female labour force participation in Malaysia. Doctor of Philosophy Thesis. University of Wollongong.

Lim, L.L. (2002). Female labor force participation. United Nations. Retrieved from https://www.un.org/development/desa/pd/sites/www.un.org.development.desa.pd/ files/unpd egm 200203 backgroundpaper female labourforce participation lim.pdf

Mishra, V., \& Smyth, R. (2010). Female labor force participation and total fertility rates in the OECD: New evidence from panel cointegration and Granger causality testing. Journal of Economics and Business, 62(1), 48-64. https://doi.org/10.1016/i.jeconbus.2009.07.006

Nakagaki, Y. (2018). Fertility, female labor participation and income in East Asia. International Journal of Development Issues, 17(1), 69-86. https://doi.org/10.1108/ijdi-06-2017-0106

Nam, S. (1991). Determinants of female labor force participation: a study Seoul, South Korea, 1970-19801. Sociological Forum, 6(4), 641-659. Retrieved from https://ur.booksc.eu/book/28632543/17cbaf

Narayan, P. K., \& Smyth, R. (2006). Female labour force participation, fertility and infant mortality in Australia: some empirical evidence from Granger causality tests. Applied Economics, 38(5), 563-572. https://doi.org/10.1080/00036840500118838

Pedroni, P. (1999). Critical values for cointegration tests in heterogeneous panels with multiple regressors. Oxford Bulletin of Economics and Statistics, 61(S1), 653-670. https://doi.org/10.1111/1468-0084.0610s1653

Pesaran, M. H., Shin, Y., \& Smith, R. P. (1999). Pooled mean group estimation of dynamic heterogeneous panels. Journal of the American Statistical Association, 94(446), 621-634. Retrieved from https://www.jstor.org/stable/2670182

Roser, M. (2014). Fertility Rate. Published online at Our World in Data. Retrieved from: https://ourworldindata.org/fertility-rate

Salamaliki, P. K., Venetis, I. A., \& Giannakopoulos, N. (2012). The causal relationship between female labor supply and fertility in the USA: updated evidence via a time series multi-horizon approach. Journal of Population Economics, 26(1), 109-145. https://doi.org/10.1007/s00148-012-0418-8

Schultz, T. W. (1961). Investment in human capital. The American Economic Review, 51(1), $1-$ 17. http://www.jstor.org/stable/1818907

Shittu, W. O., \& Abdullah, N. (2019). Fertility, education, and female labour participation. International Journal of Social Economics, 46(1), 66-82. https://doi.org/10.1108/ijse-112017-0559

Skadsen, C. (2017). Fertility and female labor force participation: the role of legal access to contraceptives. Stevenson Center for Community and Economic Development to Stevenson Center for Community and Economic Development—Student Research. 29. Retrieved from https://ir.library.illinoisstate.edu/scced/29

Solomon, B., \& Kimmel, J. (2009). Testing the inverseness of fertility and labor supply: the case of Ethiopia. Institute for the Study of Labor (IZA) Discussion Papers, No. 3949. Retrieved from http://nbn-resolving.de/urn:nbn:de:101:1-20090209192

Subramaniam, T., Loganathan, N., Yerushalmi, E., Devadason, E. S., \& Majid, M. (2016). Determinants of infant mortality in older ASEAN economies. Social Indicators Research, 136(1), 397-415. https://doi.org/10.1007/s11205-016-1526-8

The World Bank. (2019). Data on Fertility Rate (TFR) and female labor force participation (FLFP) from 1990-2018. Retrieved from https://www.worldbank.org/en/home

Tiefenthaler, J. (1997). Fertility and family time allocation in the Philippines. Population and Development Review, 23(2), 377-397. https://doi.org/10.2307/2137550 
Nazah, Duasa, \& Arifin

Fertility and Female Labor Force Participation ...

Tsani, S., Paroussos, L., Fragiadakis, C., Charalambidis, I., \& Capros, P. (2013). Female labour force participation and economic growth in the South Mediterranean countries. Economics Letters, 120(2), 323-328. https://doi.org/10.1016/i.econlet.2013.04.043

Ulku, H. (2004). R\&D, innovation, and economic growth: an empirical analysis. International Monetary Fund Working Papers, WP/04/185, pp. 2-35. Retrieved from https://scholar.google.com/scholar?q=Ulku, $\% 20 \mathrm{H} . \% 20 . \% 20 \mathrm{RD}, \% 20$ Innovation, $\% 2$ 0and $\% 20$ Economic $\% 20$ Growth: $\% 20 \mathrm{An} \% 20$ Empirical $\% 20$ Analysis, $\% 20$ International \%20Monetary $\% 20$ Fund $\% 20$ Working $\% 20$ Papers, $\% 20$ WP04185,\%20pp. $\% 202-35$ 